\title{
La explicación de los fenómenos paranormales en las filosofías de Arthur Schopenhauer y Eduard von Hartmann: Antecedentes, desarrollo y repercusiones
}

\author{
Manuel Pérez Cornejo, VIator ${ }^{1}$ \\ «There are more things in heaven and earth, Horatio, \\ than are dreamt of in your philosophy.» \\ (Shakespeare, Hamlet, Act I, Scene V)
}

«Naître, mourir, renaître encore et progresser sans cesse: telle est la loi.»

(Epitafio sobre la tumba de Allan Kardec)

\begin{abstract}
«En el fondo de la Metafísica, o mejor aún, de lo metafísico, topamos con el misterio, pero sin ese misterio no hay metafísica y sin metafísica no hay saber... El misterio debe aceptarse siempre que sea una consecuencia lógica y esa consecuencia no entrañe contradicción... La razón, razonando sobre sus límites, da razón de lo que no puede razonar.»

(GERMÁN DE ARGUMOSA)
\end{abstract}

RESUMEN: Los denominados "fenómenos paranormales", asociados a la hipotética existencia de un "mundo de espíritus", atrajeron el interés de importantes filósofos a lo largo del siglo XIX, coincidiendo con el auge del movimiento espiritista. El presente artículo, partiendo de la crítica kantiana a las experiencias visionarias de E. Swedenborg, analiza las dos principales explicaciones de estos fenómenos que se dieron en la filosofía decimonónica: la primera, planteada por A. Schopenhauer y E. von Hartmann, ponía lo paranormal en relación con la "cosa en sî" de Kant, entendida como Voluntad

\footnotetext{
${ }^{1}$ Dr. en Filosofía y licenciado en Historia del Arte. Profesor de filosofía en el IES Matemático Puig Adam de Madrid.
} 
irracional inconsciente, capaz de conectar a los individuos, al margen de las formas racionales marcadas por el principio de razón suficiente; la segunda, defendida por los partidarios del espiritismo (Aksakov, Von Hellenbach y Du Prel), interpretó el "reino de los espíritus" tomando como base el sujeto trascendental kantiano. Ambas corrientes convergen, a comienzos del siglo XX, en el análisis de los fenómenos ocultos efectuado por C. G. Jung.

PALABRAS CLAVE: "fenómenos paranormales", "espiritismo", "voluntad", "cosa en sí", "médium”, "sujeto trascendental”, "telepatía”, "magia”, "precognición”, "experiencia visionaria".

ABSTRACT: The so-called "paranormal phenomena and the "world of spirits" were two significant subjects of study for some of the most important philosophers of the nineteenth century, coinciding with the growth of the spiritualist movement. This article analyzes the philosophical interpretations of these phenomena offered by Schopenhauer and E. von Hartmann, focused on the concept of Will as "thing itself" (interpretation which denies the existence of a separated "world of spirits"), and the explanation offered by the defenders of the spiritualism (Aksakov, Von Hellenbach, Du Prel), who identified the spirits of the deceased with Kant's transcendental subject. Both lines of thinking will converge in the essay "On the Psychology \& Pathology of the so-called Occult Phenomena” by C. G. Jung (1902).

KEYWORDS: "paranormal phenomena", "spiritualism”, “will”, "thing itself”, "medium", "transcendental subject", "telepathy", "magic", "precognition", "visionary experience".

\section{Antecedentes: Los Sueños de un visionario de Kant}

La especulación filosófica que emprendieron Schopenhauer y años más tarde su seguidor Eduard von Hartmann en torno a los denominados «fenómenos ocultos o paranormales», así como el debate que le siguió, tienen su raíces, sin duda, en el opúsculo publicado por I. Kant en 1766 bajo el título Träume eines Geistersehers erläutert durch Träume der Metaphysik (Los sueños de un visionario, explicados por los sueños de la metafísica). Este librito fue redactado por Kant, influido por la lectura de Hume y Rousseau, con la aparente intención de ridiculizar las visiones del místico sueco Emanuel Swedenborg (1688-1772) y la vana pretensión dogmática de la metafísica racionalista de conocer objetos trascendentes, como el mundo, el alma o Dios. Y digo «aparente», porque creo que una relectura detenida de este texto indica que su contenido no debería ser interpretado solamente de forma negativa, como suele hacerse, sino que 
Kant, a mi juicio, anticipa en él el objetivo fundamental de su posterior período crítico: poner límites a la razón, para dejar paso libre a la fe en la existencia de un mundo espiritual2.

Es sabido que Swedenborg, tras recibir alrededor de 1744 una supuesta «llamada» para consagrarse por entero a la difusión de las revelaciones que, según su propio testimonio, le hacía Dios, creía estar en contacto directo con los ángeles y los espíritus. En sus principales obras: Arcana Caelestia (Arcanos celestes, publicada en Londres entre 1749 y 1756 , cuyos ocho volúmenes Kant leyó y estudió concienzudamente), De Caelo et de Inferno (El cielo y el infierno, 1758), De Nova Hierosolyma (La Nueva Jerusalén, 1758), Apocalipsis Revelata (El Apocalipsis revelado, 1766), y Vera Cristiana Religio (La Verdadera religión cristiana, 1771)3, Swedenborg describía sus experiencias trascendentes, en las que se le ponía de manifiesto cómo el hombre -definido, ante todo, por su espírituforma parte del mundo de los espíritus, en el que ingresa tras su muerte, ocupando un lugar intermedio entre la vida presente y el cielo o el infierno posteriores ${ }^{4}$. Dicho mundo espiritual tiene la forma de un «Gran Hombre» (el «Hombre Máximo»), una sociedad trascendente, formada por el conjunto de todos los espíritus, en la que cada uno de ellos se encuentra situado en un lugar determinado, dependiendo de sus características y su disposición moral ${ }^{5}$.

Lo primero que hace Kant es poner en valor la importante experiencia visionaria del místico sueco: afirma, en efecto, que, a pesar de que él, como filósofo, le opone desde su interior una «duda insalvable», y aunque las narraciones relativas al contacto con espíritus parecen inverosímiles, tampoco puede negarse «en absoluto la autenticidad de todas esas apariciones de espíritus» ${ }^{6}$. Kant dice claramente que, desde el punto de vista de la razón teórica, no se puede saber nada acerca de ese hipotético mundo espiritual, descrito tan detalladamente por Swedenborg: resulta imposible concebir cómo un ser simple, inmaterial y dotado de razón -ésa es la defi-

2 «Tuve (...) que suprimir el saber para dejar sitio a la fe.» (I. KANT, Crítica de la razón pura, Ed. de Pedro Ribas, Madrid, Alfaguara, 1984², B XXX, p. 27.

3 Existe una antología en castellano extraída de estos textos: $C f$. E. SwEdEnborg, $E l$ habitante de dos mundos. Obra científica, religiosa y visionaria, Ed. y Trad. de Christen A. Blom-Dahl y J. A. Antón Pacheco, Madrid, Trotta, 2000.

4 Cf. E. Swedenborg, Del Cielo y del Infierno, Trad. de Ma Tabuyo y A. López, Madrid, Siruela, $2006^{2}$.

${ }^{5}$ Cf. Pedro Chacón e Isidoro Reguera: «Introducción» a: I. KANT, Sueños de un visionario explicados por los sueños de la Metafísica, Madrid, Alianza, 1987, pp. 12-13.

6 I. KANT, Sueños de un visionario, o. cit., p. 24. 
nición que da Kant de «espíritu» ${ }^{7}$ - pueda actuar de ninguna manera, porque todos los conceptos de nuestro entendimiento resultan aplicables solamente al mundo de la experiencia espacial y material. Pero del hecho de que no sea posible probar científicamente la existencia de espíritus mediante datos empíricos dados en el espacio-tiempo de forma intersubjetiva, no puede concluirse su inexistencia. Precisamente porque no hay ningún experimento capaz de probar la existencia o inexistencia del mundo espiritual, «no se [le] puede considerar como una imposibilidad probada. (...) Por tanto se puede suponer la posibilidad de seres inmateriales sin temor a ser refutado y sin esperanza de poder demostrar esa posibilidad mediante argumentos racionales» ${ }^{8}$.

Así pues, como resulta imposible demostrar tanto la existencia como la inexistencia de los espíritus, cabe admitir su posible existencia; ahora bien: ¿hay algún argumento de peso a favor de esta posibilidad? Kant cree encontrarlo en la oscura «actividad interior» que se da en «cualquier sustancia, incluso un elemento simple de la materia», que constituye el «principio de su efectividad externa», aunque no sepamos decir en qué consiste. Ese «principio de vida parece ser de naturaleza inmaterial, puesto que toda vida se funda en la capacidad interna [de un ser] de determinarse a sí mismo según el libre albedrío». Mientras todo lo material se encuentra «externamente condicionado y forzado, (...) aquellas naturalezas que sean ellas mismas activas y que por su fuerza interna [contienen] de modo efectivo el principio vital, en una palabra, aquellas cuyo propio albedrío sea capaz de determinarse y modificarse a sí mismo», podrían existir, y ningún adversario "por muy terribles que sean sus armas» racionales, estaría en condiciones de demostrar empíricamente que no existen. Kant acude a Leibniz, quien «afirmó que este principio interior de todas la relaciones externas y de sus cambios es una fuerza representativa", si bien "hay que distinguir al menos entre seres inmateriales que contienen el fundamento de la vida animal y aquellos seres que incluyen a la razón en su propia actividad y son llamados espíritus». Estos razonamientos le llevan a Kant a reconocer sentirse «muy inclinado a afirmar la existencia de naturalezas inmateriales en el mundo y a incluir mi propia alma en la clase de estos seres» 9 .

\footnotetext{
7 Ibid., p. 32.

8 Ibid., p. 34.

${ }^{9}$ Ibid., pp. 40-41.
} 
En el capítulo II del opúsculo, Kant se atreve, incluso, a describir cómo podría ser ese mundo de los espíritus: se trataría de un mundo inmaterial (mundus intelligibilis) de seres que se impulsan a sí mismos (frente a la materia inerte) por una actividad interior, y que interactuarían directamente entre ellos, o a través de los cuerpos materiales, en virtud de ciertas leyes «pneumáticas»10:

«...considerando de este modo todos los principios de vida existentes en la naturaleza entera como en otras tantas sustancias incorpóreas en una comunidad recíproca, pero también en parte unidas a la materia, se piensa entonces en un gran todo del mundo inmaterial, en una inconmensurable, aunque desconocida, gradación de seres y naturalezas activas solo por las cuales es vivificada la materia inerte del mundo corporal. (...) De este modo, pues, el mundo inmaterial engloba dentro de sí, primero, a todas las inteligencias creadas, algunas de las cuales están unidas con la materia formando una persona, pero otras no; además, engloba a los sujetos capaces de sensación en todo género de animales y, finalmente, a todos los principios de vida estén donde estén dentro de la naturaleza, aunque no se manifiesten por ningún signo externo de movimiento voluntario. Todas estas naturalezas inmateriales, creo, ejerzan su influencia en el mundo corporal o no, todos los seres racionales cuya condición contingente sea la de un animal residente en la tierra o en otros cuerpos celestes, vivifiquen en la actualidad o en el futuro a la materia bruta o la hayan vivificado en el pasado, de acuerdo con las presentes ideas, existirían formando parte según su naturaleza de una comunidad que no se basa en las condiciones que limitan la relación de los cuerpos y en la que desaparece la distancia entre los lugares y las épocas que en el mundo visible constituyen el gran abismo que disgrega toda la comunidad. Por ello habría que considerar al alma humana ya en la vida presente unida a dos mundos a la vez, de los cuales en tanto que forma una unidad con el cuerpo sólo siente de forma clara el material, mientras que en cuanto miembro del mundo de los espíritus recibe y reenvía los influjos puros de las naturalezas inmateriales, de modo que, tan pronto como cesa aquella asociación [con la muerte], sólo queda la comunidad en la que permanece constantemente con las naturalezas espirituales y que forzosamente ha de aparecer ante la visión clara de su conciencia.» ${ }^{11}$

Esta posible «organización sistemática del mundo de los espíritus»12, aunque no puede deducirse a priori del simple concepto de «naturaleza

\footnotetext{
10 Ibid., p. 44.

11 Ibid., pp. 45-48.

12 Ibid., p. 50.
} 
espiritual», que es «excesivamente hipotético»13 ${ }^{13}$ sí podría suponerse a partir de cualquier otra observación real, generalmente admitida, como son los hechos morales, en los que parece como si una «voluntad ajena», ligada a «la fuerte ley del deber o la más débil de la bondad» se impusiese sobre «nuestro propio deseo como la condición de un asentimiento interior», haciéndonos renunciar a nuestro interés a favor del de los demás, contradiciendo nuestro egoísmo (ligado al ámbito material) ${ }^{14}$.

Los espíritus se encuentran ligados internamente, por tanto, en una «unidad moral» por la «regla de la voluntad general», igual que los cuerpos están conectados entre sí por la ley gravitatoria descubierta por Newton. Ambas leyes resultan inexplicables en su fundamento último, pero su acción es, en cualquier caso, evidente, rigiendo una el mundo nouménico y otra el mundo fenoménico (en términos del posterior Kant «crítico»).

La unidad y comunidad del mundo de los espíritus estaría basada, pues, en el «sentimiento (moral) de dependencia de la voluntad individual respecto de la voluntad general», que tiende hacia «un sistema de perfección espiritual» 15 , y por este motivo

«...el alma humana debería ocupar ya en esta vida, en función de su condición moral, su puesto entre las sustancias espirituales del universo, del mismo modo que, según las leyes del movimiento, los cuerpos del espacio cósmico están situados unos con respecto a otros en un orden proporcionado a sus fuerzas corporales. Así, cuando por fin la comunidad del alma con el mundo de los cuerpos desaparezca con la muerte, la vida en el otro mundo no sería sino una continuación natural de aquella unión que ya mantenía en esta vida, y todas las consecuencias de la moralidad en este mundo practicada volverían a encontrarse allí en los efectos de un ser que, estando en indisoluble comunidad con el mundo entero de los espíritus, ya anteriormente ha llevado a cabo allí mismo conforme a leyes pneumáticas.» 16

Tendríamos, por consiguiente, que el hombre es, a la vez, miembro de dos mundos: el «corporal» visible y el «espiritual» invisible; pero una de sus partes no tiene por qué ser consciente de la otra, sino que, a veces, «incluso en esta vida», el sujeto puede tomar conciencia de los influjos que recibe del mundo de los espíritus, no de forma inmediata, «pero sí de tal modo que, según la ley de asociación de conceptos, provoquen aquellas imágenes que están relacionadas con ellos y que suscitan representaciones

\footnotetext{
13 Id.

14 Ibid., pp. 51-52.

15 Ibid., pp. 52-53.

16 Ibid., pp. 53-54.
} 
analógicas de nuestros sentidos, que no son el concepto espiritual mismo, pero sí su símbolo»: esto es lo que sucede en el caso del sonambulismo ${ }^{17}$; y también podrían explicarse así las visiones de fantasmas atestiguadas desde la más remota antigüedad por todos los pueblos y culturas. Kant juzga que «no es improbable que las sensaciones espirituales puedan pasar a la conciencia cuando suscitan fantasías emparentadas con ellas», de manera que podrían revestirse de «los signos del lenguaje que usa el hombre en las restantes ocasiones», o «presentarse un espíritu bajo la imagen de una figura humana» ${ }^{18}$. Evidentemente, esta experiencia visionaria sería excepcional, y solamente podrían tenerla sujetos muy sensibles y excitables, que aprehenderían ciertas imágenes como si se tratase de presencias espirituales objetivas. Sus supuestas visiones serían fantasías de la imaginación, pero obedecerían a un auténtico influjo espiritual, que no puede ser sentido de forma inmediata, «pero que se trastoca en sombras de las cosas sensibles» ${ }^{19}$. Claro que, si esto es así, Kant reconoce que resulta imposible distinguir con claridad al fantasioso del auténtico visionario, y las simples quimeras de las imágenes realmente suscitadas por una influencia espiritual.

La conclusión a la que llega Kant es que:

«...ya no puede resultar embarazoso ofrecer una probable explicación racional de las historias sobre fantasmas que tantas veces se le presentan a los filósofos e, igualmente, de toda clase de influjos de espíritus de los que se habla por doquier. Ciertamente las almas separadas y los espíritus puros nunca pueden presentarse ante nuestros sentidos externos ni tener comunicación con la materia, pero sí en cambio actuar sobre el espíritu humano que pertenece junto con ellos a una gran república, de tal modo que las representaciones que despiertan en él se cubren, según las leyes de la fantasía, de imágenes asociadas y provocan la apariencia de que los objetos que les corresponden están fuera del espíritu. Esta ilusión puede alcanzar a cada uno de los sentidos, y por más que esté mezclada con fantasmas disparatados, no debe uno negarse a suponer en ella una influencia espiritual.» 20

Kant señala incluso que, si alguien tuviese verdadera capacidad para conocer directamente el mundo de los espíritus, estaría como alienado, perdido en él, y daría la impresión de estar loco, visto desde nuestro mun-

\footnotetext{
17 Ibid., pp. 56-57.

18 Id.

19 Ibid., p. 58.

20 Ibid., pp. 59-60.
} 
do. Por eso la experiencia visionaria solo puede darse de forma fugaz y repentina, y va acompañada de un aire de ensoñación fantástica, pues se aparta transitoriamente de la experiencia normal.

Esta descripción de la hipotética estructura del mundo de los espíritus y de la experiencia que cabría tener del mismo, es la que lleva a Kant a criticar las visiones de Swedenborg, porque él tomaba tales visiones como una experiencia real, describiendo aquello que veía en ellas como algo que existe objetivamente, cuando podrían tratarse perfectamente de alucinaciones o ilusiones creadas por su cerebro ${ }^{21}$. Nunca podremos decidir taxativamente si tales visiones, o las historias de fantasmas, son meras fantasías, o corresponden a seres reales. Mas, habida cuenta de que no es contradictoria la posible existencia de dicho mundo; que en nuestro espíritu pesa con gran fuerza la esperanza en la permanencia tras la muerte; que existen, además, data morales, no sensibles (accesibles a nuestro «corazón»), que apuntan a una conexión moral entre las voluntades en una voluntad general ${ }^{22}$, y que, en fin, las razones anteriormente expuestas, muestran una actividad interna del sujeto, independiente de la materia, «la balanza del entendimiento no es [aquí] totalmente imparcial» 23 , y por eso tendemos a conceder mas crédito a la existencia de ese mundo de espíritus que a su inexistencia, o, como dirá luego el Kant crítico: a postular la fe en la inmortalidad del alma y un reino de los fines, que reuniría a todas las almas y a todos los seres espirituales. En palabras de Pilar Ramiro de Pazos, «Kant se abre a la existencia de un mundo espiritual afirmado en el orden epistemológico de los postulados»24; de ahí que no podamos «negarles del todo verdad a las diversas historias sobre espíritus, (...) otorgándoles (...) cierto crédito a todas tomadas en su conjunto» 25 . Las extraordinarias visiones y predicciones realizadas por el teósofo sueco, corroboradas por numerosos testigos ${ }^{26}$, igual que su vívida descripción del mundo de los espíritus -que, por lo demás coincide muy exacta-

21 Ibid., capítulo 3, pp. 61 y ss.

22 Ibid., pp. 110-111.

23 Ibid., p. 72.

24 Pilar Ramiro de Pazos, en: Germán de Argumosa, Más allá de los fenómenos paranormales, Madrid, Oberón, 2014, p. 554, n. 31.

25 I. KANT, Sueños de un visionario, o. cit., p. 74.

26 Cf. la carta de Kant a la señorita Carlota von Knobloch, fechada el 10-08-1763 (I. KANT, Sueños de un visionario, o. cit., pp. 113 y ss.). Me inclino a considerar esta carta auténtica, a pesar de las dudas que se han manifestado sobre ella, dada la coincidencia que entiendo existe entre su contenido y el del opúsculo kantiano que estamos comentando. 
mente con la organización del mundo espiritual que Kant ha descrito 27 , resultan, si no verdaderas, sí, al menos, muy verosímiles, y nada, ni nadie, podrá refutarlas jamás. «[El] alma recta [de un hombre que nunca ha] podido soportar la idea de que todo termine con la muerte» 28 debe esforzarse por cumplir en vida su deber moral, y al hacerlo le cabe albergar la firme esperanza de que tras la muerte su alma inmortal ingresará en el mundo eterno de los espíritus.

\section{Breve panorámica del mundo de lo paranormal en la época de Scho- penhauer y Eduard von Hartmann}

Antes de pasar a exponer las teorías de Schopenhauer y Eduard von Hartmann en relación con los fenómenos espiritistas, conviene trazar una panorámica del statu quo sobre estos temas en su época. Ulrich Linse ha señalado que el avance del escepticismo cientificista y del capitalismo industrial a lo largo del siglo XIX provocó una «crisis de conciencia» entre los europeos y su «huida al irracionalismo», lo cual se tradujo en un creciente interés por los «fenómenos ocultos»; sin embargo, fue ese mismo cientificismo el que condujo a los propios ocultistas a tratar de extender la metodología experimental al estudio de unos fenómenos que antes se situaban al margen de cualquier experimentación contrastable ${ }^{29}$. Los ocultistas mantenían la posibilidad de comprobar empíricamente los fenómenos paranormales, e incluso afirmaban que la reciente teoría de la evolución darwinista hacía necesario admitir la continuidad entre la vida material y espiritual, así como el ulterior desarrollo de esta última en mundos superiores. El ocultismo se fue convirtiendo, así, en una especie de «fe de recambio», encargada de sustituir a la desfalleciente religión tradicional, «una especie de síntesis entre el moderno pensamiento científico y las ideas tradicionales sobre Dios, el ser humano y el mundo» 30 . El ocultismo, en suma, era una parte más de la ciencia, y estaba en condiciones, al fin, de suprimir la barrera crítica alzada por Kant frente a lo sobrenatural, gracias a los supuestos datos expe-

27 Ibid., pp. 81-89 y 93-100.

28 Ibid., pp. 111-112.

29 Cf. U. Linse, Videntes y milagreros. La búsqueda de la salvación en la era de la industrialización, Madrid, Siglo XXI, 2002, p. 2 (debo a la amable recomendación del profesor D. Fernando Negredo del Cerro el conocimiento de este documentado estudio histórico).

30 U. LINSE, Videntes y milagreros, o. cit., p. 10. 
rimentales aportados por los propios espíritus a través de novedosos procedimientos técnicos como el «psicógrafo»" o el «espirituscopio»31.

Aunque en la década de los treinta se registraron fenómenos de este tipo ligados a movimientos religiosos apocalípticos, como el encabezado por Edward Irving, o las comunidades shakers de EE. UU., las manifestaciones que marcarían un antes y un después en este ámbito fueron las que tuvieron lugar en 1848 en Hydesville, en el seno de la familia Fox. El mensaje que transmitían los espíritus no podía ser más claro: «Nosotros, los muertos -decían-, vivimos y podemos volver a ponernos en contacto con vosotros. (...) Nuestro objeto es que la humanidad entera viva en armonía y que los escépticos se convenzan de la inmortalidad del alma» ${ }^{32}$. En 1850, el médium Andrew Jackson Davies publicaba The Great Harmonia. A Philosophical Revelation of the Nature, Spiritual and Celestial Universe, obra en 5 volúmenes, en la que utilizaba las revelaciones espiritistas para avalar la existencia del mundo espiritual descrito por Swedenborg (con cuyo espíritu decía estar en contacto); en 1854 se fundaba en Nueva York la primera asociación espiritista regular, y en 1855 -fecha de la primera sesión de «mesas giratorias o parlantes» en Bremen- ya había un total de 28 millones de norteamericanos que se declaraban partidarios del credo espiritista. Surgió entonces una especie de «Internacional Espiritista» dividida en dos tendencias, una, por así decirlo, «respetable», que atrajo a las clases media y alta, sobre todo en Alemania, y otra más popular, una especie de «espiritismo de izquierdas», ligado al socialismo utópico de Owen y Fourier, que se desarrollaría sobre todo en Inglaterra ${ }^{33}$. Aunque en sus escritos Schopenhauer suele referirse más bien a textos precursores del espiritismo -en especial Die Seherin von Prevorst- de Justinus Kerner (1829), o los escritos de J. H. Jung-Stilling (Szenen aus dem Geistesreiche, 1795), parece poco probable que un lector tan atento como él a novedades aparecidas en diarios y revistas no conociese estos hechos, siquiera como noticias periodísticas.

En cambio, el contexto en el que desarrolló Eduard von Hartmann su explicación de los fenómenos espiritistas (el último cuarto del siglo XIX) fue ya el de la plena difusión del movimiento. En Francia, Allan Kardec

31 Ibid., pp. 11-13.

32 Ibid., p. 51. y A. CONAN Doyle, Historia del espiritismo. Sus hechos y sus doctrinas, Madrid, Eyras, 1983, pp. 66-67.

33 Ibid., pp. 2-3, 30 y ss., 51-85; cf. también: A. CONAN DoYLE, Historia del espiritismo. Sus hechos y sus doctrinas, o. cit., pp. 33-95. 
(León Hippolyte Dénizard Rivail, 1804-1869) había publicado el Libro de los espíritus en 1856, cuatro años antes de fallecer Schopenhauer, seguido del Libro de los médiums (1861), El Evangelio explicado por los espíritus (1864), y Génesis (1867), obras en las que ligaba la creencia en los espíritus con las doctrinas del progreso y la reencarnación, sosteniendo que «el progreso espiritual de los humanos se efectúa a través de una serie de reencarnaciones» ${ }^{34}$, siempre progresivas, nunca retrógradas, necesarias para que el espíritu del sujeto vaya ingresando en niveles superiores de existencia ${ }^{35}$. Al mismo tiempo, el espiritismo era introducido con fuerza en Inglaterra en 1852, a través de la médium Hayden, quien entró en contacto con el lógico y matemático Augustus de Morgan y su esposa, la cual publicaría en 1863 el libro De la materia al espíritu, en el que se recogían sus diez años de experiencias con lo sobrenatural. Entre 1870 y 1874 tuvieron lugar las famosas investigaciones realizadas por William Crookes, coincidiendo con la fundación de la Sociedad Británica Nacional de Espiritistas (en 187336), y la Society for Psychical Research (Londres, 1882). En 1875, el naturalista Alfred R. Wallace publicó su famoso libro Sobre los milagros y el espiritismo moderno, tras haber asistido a las sesiones del médium Monck, mientras desarrollaban su actividad infinidad de "contactados" con el Más Allá: Daniel Douglas Home, los hermanos Davenport, Eddy y Holmes... ${ }^{37}$ Asimismo, las experiencias de J. K. Fr. Zöllner, realizadas entre 1877 y 1878 en colaboración con Weber, Schliebner y Fechner, sobre la actividad del médium Henry Slade; las sesiones celebradas en 1892 con la médium Eusapia Palladino, en las que participaron Lombroso, Schiaparelli, Aksakov, Du Prel y Richet; las investigaciones realizas por William James en el caso de la médium británica Leonora Piper ${ }^{38}$, así como las innumerables materializaciones de ectoplasmas,

34 A. CONAn Doyle, Historia del espiritismo, o. cit., p. 363.

35 Allan Kardec, El libro de los espíritus, Madrid, ELA, 2006, p. 138.

36 Tras comprobar escrupulosamente las revelaciones procedentes del espíritu de «Catalina King», Crookes manifestó: «Todo lo que yo puedo decir es que hay seres invisibles e inteligentes que afirman ser los espíritus de personas que murieron (...). [Mis] experimentos [están] encaminados a demostrar que fuera de nuestros conocimientos existe una Fuerza ejercitada por una inteligencia distinta de la inteligencia común de los mortales. (...) Jamás he tenido motivo para cambiar de opinión acerca del particular. (...) Es perfectamente cierto que hay una conexión entre este mundo y el Más Allá.» (Cf. A. ConAN DOYLE, Historia del espiritismo, o. cit., pp. 189-90).

37 Ibid., pp. 225 y ss., 191 y ss.

38 Ibid., pp. 218 ss., 249 ss., y pp. 295 y ss. 
aportes, modelados, escritura automática, o fotografías registradas ${ }^{39}$, parecían probar irrefutablemente la continuidad de la vida tras la muerte, así como la posibilidad de una comunicación extraterrenal.

\section{La explicación inmanente de los fenómenos paranormales en el marco de la «metafísica de la voluntad» de Arthur Schopenhauer}

Resulta curioso comprobar cómo el debate optimismo versus pesimismo penetró incluso en el ámbito de lo paranormal. Schopenhauer y Eduard von Hartmann, por un lado, y los filósofos partidarios del espiritismo -Hellenbach, Aksakov, Du Prel-, por otro, intentaron ofrecer sendas explicaciones de estos fenómenos, declarando inspirarse, en ambos casos, en el idealismo trascendental de Kant; pero, como vamos a ver a continuación, sus propuestas explicativas son muy diferentes: mientras los maestros pesimistas ofrecen una explicación inmanente de lo paranormal, basada en una «metafísica de la voluntad», muy escéptica con la posible existencia separada de un mundo de espíritus, los filósofos espiritistas plantean un realismo trascendental ${ }^{40}$, que afirma la existencia efectiva de dicho mundo, abriendo la puerta a la esperanza optimista en la existencia de otra vida. Identifican el «sujeto trascendental» kantiano con el «alma» o el «espíritu», diferenciándolo de la «personalidad» empírica, ligada al espacio-tiempo y a la ley de la causalidad, atribuyéndole, además, capacidades perceptivas trascendentales, y considerando que las manifestaciones espiritistas ofrecen esa prueba empírica definitiva de la existencia del mundo de los espíritus que Kant había echado en falta.

En el capítulo titulado Magnetismo animal y magia, incluido en Sobre la voluntad en la naturaleza (1836), así como en los ensayos Especulación trascendente sobre la aparente intencionalidad en el destino del individuo y, sobre todo, Ensayo sobre las visiones de fantasmas, contenidos ambos en Parerga y paralipomena (1851), Schopenhauer se propone ofrecer una explicación de lo paranormal plenamente ajustada -asegura- a los planteamientos del idealismo kantiano, en su aspecto más crítico. En este sentido, rechaza cualquier posible explicación espiritualista de los fenómenos paranorma-

39 Las primeras tomas fotográficas espiritistas son de 1861, aunque parece que R. Boursnell ya había llevado a cabo algunos registros en 1851, que no se han conservado (ibid., pp. 329 y ss.)

40 La diferencia entre las explicaciones «inmanente o animista» $\mathrm{y}$ «trascendental» de los fenómenos paranormales la aclara perfectamente Germán de Argumosa: cf. Más allá de los fenómenos paranormales, o. cit., p. 129. 
les, pues no acepta la división tradicional entre alma y cuerpo, ni la existencia de un hipotético mundo de espíritus, separado del mundo físico ${ }^{41}$.

Ironiza Schopenhauer sobre el desprecio que, según él, había sentido el siglo XVIII -la supuesta «época de la razón»- hacia los fenómenos ocultos $^{42}$; en su época, en cambio, estas cuestiones han vuelto a cobrar plena actualidad, de manera que, sentencia, «quien ponga en duda hoy en día los hechos del magnetismo animal y de clarividencia no ha de ser tachado de incrédulo, sino de ignorante» ${ }^{43}$. Se trata, por consiguiente, de un tipo de fenómenos reconocidos por todas las épocas, y que la filosofía no puede negar, ni rehuir, sino afrontar y explicar. Rechazar los fenómenos paranormales supone un gran atrevimiento, pues implica considerar que el mundo es totalmente permeable a la razón, sin percatarse de que «estamos sumidos en un mar de enigmas y de incomprensibilidades, y que no conocemos inmediatamente a fondo las cosas ni a nosotros mismos» ${ }^{44}$. $\mathrm{Si}$, efectivamente, conociésemos inmediatamente las cosas en sí, no existiría ningún trasfondo en la realidad que pudiese escapar a nuestro poder de penetración intelectual, $\mathrm{y}$ «estaríamos autorizados a rechazar a priori e incondicionalmente (...) toda presciencia del futuro, todas las apariciones de ausentes o de moribundos, o aun de difuntos, y toda influencia mágica» ${ }^{45}$; mas el idealismo kantiano enseña, por el contrario, que no conocemos más que las leyes de los fenómenos, y que la esencia de la realidad, el noúmeno -que abarca también nuestro propio interior-, escapa a nuestro conocimiento, siendo de ese misterioso fondo último de la realidad del que dependen, seguramente, los sucesos paranormales, sobre los cuales «hay que esperar decisión a posteriori, sin anticiparnos a ella» ${ }^{46}$.

41 A. Schopenhauer, Parerga y paralipomena (Escritos filosóficos sobre diversos temas), Ed. de J. R. Hernández Arias, L. F. Moreno Claros y A. Izquierdo, Madrid, Valdemar, 2009, I, p. 315.

42 Algo en lo que, por otra parte, Schopenhauer se equivoca: hay casi más "sombras" que "luces" en la época de la Ilustración, cf.: A. FAIVRE, El esoterismo en el siglo XVIII, Madrid, EDAF, 1976.

43 A. SChOPEnhauer, Parerga y paralipomena, o. cit., p. 250. En sus conversaciones con J. Frauenstädt, Schopenhauer considera las cuestiones paranormales como "los problemas metafísicos más importantes y difíciles", cf. Conversaciones con A. Schopenhauer. Testimonios sobre la vida y la obra del filósofo pesimista (Introducción, selección, notas y traducción de L. F. Moreno Claros), Acantilado, Barcelona, 2016, p. 120 y ss.

44 A. Schopenhauer, Sobre la voluntad en la naturaleza, Trad. de Miguel de Unamuno, Madrid, Alianza, 1979², p. 163.

45 A. SCHOPENHAUER, Sobre la voluntad en la naturaleza, o. cit, pp. 163-164.

46 Ibid., p. 164. 
Antes, afirma Schopenhauer, para explicar los fenómenos ocultos, como el magnetismo animal (hipnotismo), movimientos de cuerpos a distancia, clarividencia, curas por simpatía, o el "mal de ojo", se utilizaban conceptos materiales como el «éter cósmico», o el denominado «fluido nervioso» 47 ; él, en cambio, sostiene que el «agente tan profundo», que «provoca afectos (...) tan opuestos al curso regular de la naturaleza» no es otro que la voluntad, ese principio metafísico único del mundo, «la cosa en sí, lo único real en toda existencia, el núcleo de la Naturaleza», que es la que rompe los límites que separan a los individuos en el plano fenoménico, estableciendo entre ellos una «comunidad de pensamientos y de movimientos volitivos (...), un estado de clarividencia [que] suplanta al que concierne a la mera fenomenalidad, a las relaciones condicionadas por espacio y tiempo, que son cercanía y lontananza, presente y futuro» ${ }^{48}$, que rigen el mundo ideal de nuestra representación. La voluntad establece, por consiguiente, un «enlace subterráneo, gracias al cual se pudiera obrar desde un punto del mundo fenoménico inmediatamente sobre otro cualquier punto de él, por un nexum metaphysicum» 49 , en el plano de la natura naturans, por detrás de la compleja tramoya de fenómenos que componen la natura naturata. Mientras los doctos suelen burlarse de estos hechos «mágicos», el pueblo y los filósofos hermetistas -Schopenhauer cita a Roger y a Francis Bacon (quien definía la magia como «metafísica práctica» ${ }^{50}$ ), Paracelso, Campanella, Agrippa de Nettesheim, Vanini, Van Helmont, Pomponazzi o J. Böhme- siempre reconocieron su existencia, aunque piensa que solo su propia filosofía le permite a la magia «darse cuenta de sí misma» (esto es: dar cuenta de sus manifestaciones). Si antaño se buscó la causa de la acción mágica en el poder de genios y demonios (magia "negra"), o de ángeles (magia "blanca"), ahora el concepto de la voluntad permite entender esos fenómenos a partir de la conexión que este principio metafísico establece entre todos los seres de la realidad, por debajo de nuestra «representación espacio-temporal y causal» de ellos ${ }^{51}$ :

«(...) La acción directa de la VOLUNTAD sobre otras voluntades y a distancia (...) es precisamente el carácter fundamental de lo que designa la

47 Cf. F. A. Mesmer, Los fundamentos del magnetismo animal, Índigo, Barcelona, 2006, p. 80 .

48 A. SCHOPENHAUER, Sobre la voluntad en la naturaleza, o. cit., pp 153-159.

49 Ibid., p. 166.

50 Sobre la magia como «metafísica práctica», ibid., p. 159, y Parerga y paralipomena, o. cit., p. 290.

51 Ibid., pp. 159 y 166-170. 
palabra desacreditada "magia". Esta es una acción directa de nuestra propia voluntad liberada de las condiciones causales de la acción física, esto es, del contacto en el sentido más amplio de la palabra. (...) Lo mágico (...) es una actio in distans real y completa, como la auténtica mántica, por ejemplo la clarividencia del sonámbulo, es passio in distans (...). En ambos casos, actuamos independientemente de los límites a que dan lugar el espacio, el tiempo y la causalidad, lo que de otro modo en la vida cotidiana sólo podemos hacer dentro de esos límites. Nuestra esencia más íntima, la cosa en sí, ha eliminado esas formas del fenómeno y aparece libre de ellas. (...)

"Magnetismo animal, curas simpáticas, magia, segunda vista, apariciones y visiones de todo tipo son fenómenos emparentados, ramas de un mismo tronco, y proporcionan indicios ciertos e irrefutables de un nexo entre los seres que reposa sobre un orden totalmente diferente de cosas al de la naturaleza cuya base está formada por las leyes del espacio, el tiempo y la causalidad. (...) La voluntad, como cosa en sí, está fuera del principium individuationis (tiempo y espacio), por el que los individuos son SEPARADOS; los límites que éste crea no existen entonces en la voluntad. Esto explica, en lo que puede alcanzar nuestra inteligencia cuando entramos en este dominio, la posibilidad de una acción DIRECTA entre individuos, independientemente de su proximidad o lejanía en el espacio.» 52

Por lo que se refiere a las visiones de fantasmas y los fenómenos que habitualmente van asociados a ellos: golpes, ruidos, voces, etc., Schopenhauer considera que, para descartar posibles fraudes, hay primero que definir bien lo que se entiende por «fantasma»: desde luego, no se trata de un cuerpo, porque los espíritus están por definición desencarnados, sino, como acabamos de indicar, de imágenes, golpes, ruidos, voces..., es decir, representaciones, aprehendidas por el intelecto intuitivo, y totalmente indiscernibles de las que produciría un cuerpo físico, pero «sin la presencia real de ese cuerpo»53. El problema es: ¿cómo explicar que en ausencia de un cuerpo se produzca sobre nuestra intuición una acción idéntica a la de un cuerpo?

En la gnoseología schopenhaueriana, derivada de la kantiana, la intuición del mundo exterior en estado de vigilia se construye a partir de la sensación y del entendimiento (cerebro), aplicando a las sensaciones las formas a priori del espacio-tiempo y la ley de la causalidad; pero, ¿qué sucedería si los estímulos que actúan sobre el cerebro y sus formas a priori procediesen del interior del organismo? Adoptando el punto de vista trascendental, el contenido percibido en ambos casos es ideal, y depende de la relación entre el fenómeno y la cosa en sí que, como hemos visto,

52 A. SCHOPENHAUER, Parerga y paralipomena, o. cit., pp. 286-326.
53 Ibid., pp. 247-248. 
procede de la voluntad: ésta es, pues, el principio metafísico que «subyace tanto a las apariciones de los cuerpos como a las de los fantasmas» ${ }^{54}$. Solo esta explicación idealista permite soslayar la crítica que Kant realizaba, como vimos más arriba, a la interpretación espiritualista de los fenómenos paranormales.

Los sueños, dotados muchas veces de una claridad y objetividad asombrosas, demuestran que en el interior de nuestro cerebro se pueden formar imágenes semejantes a las que producen los cuerpos, sin influencia de los mismos, dependiendo solamente de la actividad del nervio simpático, o centro nervioso interno; es este «órgano de los sueños», como lo llama Schopenhauer, el que nos permite entender el fenómeno de la deuteroscopia, o segunda vista (second sight) -emparentado con el estado de «duermevela», en el que nos parece que lo soñado es real-, o el sonambulismo, en el que el sujeto, profundamente dormido, es capaz de realizar acciones dotadas de total previsión y clarividencia; también permite entender otras manifestaciones paranormales, como la segunda visión retrospectiva (retrospective second sight), en la que el sujeto cree ver personas, o partes de ellas, que han vivido hace tiempo, y que suelen estar vinculadas al lugar en el que vivieron o padecieron en el pasado («casas encantadas, impregnadas, o infestadas» de fantasmas), las visiones proféticas, la aparición de moribundos ante sus familiares o amigos (provocada por la intensidad con las que piensan en ellos en el momento del óbito), los sueños simpáticos, la aparición de dobles, la comunicación a distancia (telepatía)...55: todos estos eventos tendrían su origen en el interior del sujeto, en su «centro» metafísico (la voluntad), pero se revisten de las formas representativas usuales, por lo que dan lugar a esa «intuición misteriosa» por la que el sujeto capta percepciones semejantes a las del estado de vigilia ${ }^{56}$. Ese centro, en el que reside la voluntad, es el que conecta entre sí a todos los individuos, más allá de las formas ilusorias que rigen la conciencia, aunando desde dentro todos los fenómenos, pasados, contemporáneos o futuros, de forma atemporal y a-espacial:

«Lo delirantemente portentoso y lo absolutamente increíble de la clarividencia del sonámbulo (confirmada hasta ahora por el acuerdo de cientos de testimonios dignos de fe), ante la cual se abre lo oculto, lo ausente, lo lejano, incluso lo que todavía dormita en el seno del futuro, pierde al menos su incomprensibilidad absoluta si nos atrevemos a aceptar (...) que el

\footnotetext{
54 Ibid., pp. 248-49.

55 Ibid., pp. 301 y ss.

56 Ibid., pp. 250-274.
} 
mundo objetivo es un mero fenómeno cerebral, pues el orden y regularidad, que se fundan en el espacio, el tiempo y la causalidad (como funciones del cerebro) son suprimidas en cierto grado en la clarividencia del sonámbulo. Gracias a la doctrina kantiana de la idealidad del espacio y del tiempo comprendemos que la cosa en sí, es decir, lo único verdaderamente real en todos los fenómenos, libre de esas dos formas del intelecto, no conoce la diferencia entre lo cercano y lo lejano, entre lo presente, lo pasado y lo futuro. Por eso las diferencias que se fundan en esas formas de intuición no se muestran como absolutas, y ya no ofrecen barreras infranqueables para el modo de conocimiento en cuestión, modificado en esencia por la transformación de su órgano. Si por el contrario, el espacio y el tiempo fuesen absolutamente reales y perteneciesen a la esencia en sí de las cosas, entonces ese don de la profecía de los sonámbulos, como en general toda visión de lo lejano y del futuro, sería un milagro totalmente incomprensible. Por otra parte, la doctrina de Kant recibe incluso, hasta cierto punto, una confirmación fáctica de los hechos aquí tratados. Pues si el tiempo no es una determinación de la esencia verdadera de las cosas, el antes y el después pierde su significado en relación con ésta. Según esto, un acontecimiento debe poder ser conocido tanto antes de que suceda como después. Toda mántica, ya sea en sueños, en la visión del futuro del sonámbulo, en la segunda vista o de otra forma, sólo consiste en el hallazgo del camino hacia la liberación del conocimiento de la condición del tiempo.» 57

Todas las experiencias visionarias, aunque están dotadas de cierta tonalidad onírica de fondo - puesto que se basan en la intensa actividad del órgano del sueño que hemos descrito-, parecen al principio completamente reales, y por eso no suelen causar temor cuando se producen; solo provocan inquietud más tarde, al comprobar que rebasan el marco de nuestros procedimientos cognitivos habituales.

Especialmente las visiones de personas fallecidas resultarían "lógicas" dentro de esta explicación, ya que en la filosofía schopenhaueriana la muerte no supone más que la aniquilación del fenómeno, pero no de la voluntad, que puede seguir actuando al margen del cuerpo en el que se objetivaba anteriormente 58 , y puede suscitar una nueva representación en varias personas, que afirman haber visto la aparición ${ }^{59}$. Estas visiones de

57 Ibid., pp. 285-286.

58 Ibid., pp. 329 y 781 ss.

${ }^{59}$ Schopenhauer considera que, si numerosos testigos afirman haber presenciado una aparición, el fenómeno paranormal debe considerarse «objetivo», mientras que, si únicamente cuenta con un testigo, no es posible determinar si se trata de una ilusión subjetiva: cf. Ibid., pp. 316-322. 
fantasmas suelen tener un carácter onírico, pero como en la visión normal y en la paranormal actúa el mismo principio metafísico de la voluntad, bien desde fuera, bien desde dentro, si la acción interna ejercida por la voluntad es muy intensa, como ambas representaciones están sometidas a las mismas formas ideales, no resulta fácil distinguir en ocasiones al fantasma de un cuerpo físico real ${ }^{60}$. Además, esas apariciones suelen atribuirse a la persona del muerto, es decir, a un «espíritu», cuya supervivencia hemos visto rechazada por Schopenhauer, porque lo que permanece es la voluntad, no el intelecto, que perece, al estar ligado a fenómeno corporal; por eso, no se explica cómo podría conocer el muerto a los vivos, ni cómo podría actuar sobre ellos de forma intelectual61. Schopenhauer considera, por tanto, bastante dudoso que las personas muertas pueden aparecérsenos realmente; pero hay tantos testimonios a favor de estas apariciones desde la más remota antigüedad, que él trata de incluir también estos fenómenos en su teoría, en vez de rechazar hipócritamente su existencia:

«(...) si quisiéramos otorgar alguna verdad a los hechos narrados y afirmados por tantos lados tan distintos, que dan firme testimonio de la acción objetiva de los muertos, tendríamos que explicarla así: en estos casos, la voluntad de un muerto seguiría dirigiéndose apasionadamente hacia los asuntos terrenales y al estar ahora privada de todo medio físico para actuar sobre ellos, recurriría entonces al poder mágico que le corresponde a su naturaleza original, es decir, metafísica, y por tanto, en la muerte como en vida. (...) Sólo gracias a este poder mágico la voluntad podría seguir haciendo lo que pudo hacer en vida, en especial ejercer una actio in distans real, sin ayuda corpórea, y así actuar directamente sobre los demás, sin mediación física alguna, afectando a su organismo de tal manera que tengan que representarse intuitivamente unas figuras en el cerebro que de otro modo sólo se producirían como consecuencia de una acción externa sobre los sentidos. Además, como esta acción sólo se concibe que se pueda ejecutar mágicamente, es decir, mediante la esencia íntima de las cosas que es idéntica en todas las cosas -la natura naturans-, podríamos (...) no limitar esta acción a los organismos humanos, sino atribuirla también como algo no totalmente imposible, a los cuerpos sin vida, es decir, inorgánicos, a los que de este modo podría mover, con el fin de escapar así a la necesidad de tachar de falsas ciertas historias dignas de crédito.» 62

\footnotetext{
60 Id.

$61 C f$. «Sobre la teoría de la indestructibilidad de nuestro verdadero ser por la muerte», ibid., pp. 781 y ss.

62 Ibid., p. 331; la argumentación de Schopenhauer recuerda a lo expuesto por Platón en Fedón, 480d-535d.
} 
Comparativamente, resulta curioso ver la diferencia que existe entre las argumentaciones de Kant y Schopenhauer. Vimos como Kant ponía entre paréntesis los fenómenos paranormales (como dice Schopenhauer «la magia»), reduciéndolos a un mero postulado basado en data morales, que avalan la posible conexión nouménica entre las voluntades de los individuos en el plano de una voluntad general; Schopenhauer, en cambio, parte del Faktum que supone, según él, la existencia del núcleo metafísico de la voluntad que late en nuestro interior, y considera que precisamente la magia y lo paranormal -entre otras cosas- demuestran la existencia de ese núcleo metafísico y la idealidad de nuestro conocimiento del mundo:

«[Los fenómenos ocultos] proporcionan ante todo (...) una confirmación fáctica tan inesperada como segura de la doctrina fundamental kantiana de la oposición entre fenómeno y cosa en sí y las leyes de ambos. La naturaleza y su orden es, según KANT, un puro fenómeno; como lo contrario de este orden vemos que todos los hechos en cuestión llamados mágicos tienen su origen directamente en la cosa en sí y dan lugar a fenómenos en el mundo de la apariencia que, según las leyes de éste, nunca se pueden explicar, por lo que son negados hasta que cien experiencias ya no permiten su negación. Pero no solo la filosofía kantiana sino también la mía recibe por la investigación más profunda de estos hechos una importante confirmación por el facto de que en todos estos fenómenos el verdadero agente (la fuerza motriz) es la sola voluntad.» ${ }^{63}$

¡De manera que sería el ámbito de lo paranormal, el de la magia o «metafísica práctica», uno de los principales avales de la filosofía schopenhaueriano-kantiana! No sabemos qué habría pensado Kant acerca de este inesperado aliado de su idealismo crítico.

\section{Carl du Prel, Lazar von Hellenbach y la formulación del «realismo tras- cendental»}

Influido por Kant, Schopenhauer, Darwin y Eduard von Hartmann, Carl du Prel (1839-1899) fue seguidor durante bastantes años de este último; sin embargo, tras conocer las investigaciones de Karl Friedrich Zöllner64 y los escritos de Lazar von Hellenbach -por recomendación del

\footnotetext{
63 Ibid., p. 288.

64 Zöllner -profesor de física y de astronomía en la Universidad de Leipzig, influido por Kant, Schopenhauer y Helmholtz-, tras los experimentos realizados en 1877 con el
} 
propio Hartmann-, además de practicar él mismo el espiritismo, publicó su Philosophie der Mystik (Filosofía de la mística, 1885), obra en la que rompía con su mentor intelectual. El principal conflicto entre ambos estribaba en la diferente concepción que ambos pensadores mantenían sobre la vida post mortem: mientras Du Prel planteaba una permanencia de la individualidad, Von Hartmann había propuesto unos años antes en su Philosophie des Unbewussten (Filosofía del Inconsciente, 1869) una permanencia abstracta del sujeto, "diluido", por así decirlo, en la sustancia cósmica impersonal del Inconsciente.

Hablaremos de Du Prel más adelante; ahora vamos a analizar brevemente las contribuciones de Lazar von Hellenbach (1827-1887) al problema que estamos exponiendo. Von Hellenbach retomaba las reflexiones de Kant, pero las interpretaba sesgadamente, a fin de acordarlas con las manifestaciones espiritistas, desconocidas en la época del filósofo de Königsberg. En su libro Geburt und Tode als Wechsel der Anschuungsform oder die Doppel-Natur des Menschen (El nacimiento y la muerte como cambio de la forma de intuición, o la doble naturaleza del hombre), publicado también en 1885, Hellenbach identifica al «sujeto trascendental» de Kant con el viejo concepto del «alma» o «espíritu»-cuya inmortalidad es para Kant, como sabemos, un mero postulado práctico-, y, por otra parte, transforma la distinción schopenhaueriana entre «voluntad» y «representación» en la distinción «alma» / «conciencia». De ahí deduce la naturaleza dual del ser humano (reconocida por filosofías antiguas como la hindú o el platonismo, y apoyada, según él, por las teorías de Kant y Schopenhauer): Kant habría demostrado que la conciencia es solo una función del cerebro, una especie de «espejo», en el que se reflejan los datos externos e internos para formar nuestra experiencia del mundo como «representación», dando lugar a la personalidad «empírica»; pero detrás de esas imágenes fenoménicas que integran nuestra personalidad e incluso nuestro carácter, los fenómenos del sonambulismo, clarividencia, etc., demuestran que se oculta «otra realidad completamente diferente», que no es la voluntad genérica de Schopenhauer, sino el sujeto trascendental, un «espíritu» o «meta-organismo», que reside en lo que Zöllner

médium H. Slade (Vid. supra, § 2), llegó «a un convencimiento completo de la realidad de los hechos observados, con exclusión de toda trampa y prestidigitación» (Cf. A. CONAN Doyle, Historia del espiritismo, o. cit., p. 219). Relató sus sesiones espiritistas en su libro Física trascendental (Cf. J. C. Fr. Zöllner, Física trascendental, (1878), Boston, Colby \& Rich, 1881 (survivalafterdeath.blogspot.com.e/2012/01/fisica-trascendental-libro-j-c-f.html) 
llamaba la «cuarta dimensión» ${ }^{65}$, y que se rige por leyes diferentes de las naturales.

«Kant ha demostrado, estudiando nuestra facultad cognoscitiva, que el mundo tal como está en nuestra cabeza, no está constituido en absoluto como nos lo representamos; mediante esta investigación han surgido contraposiciones, a las que se les han adjudicado determinadas denominaciones. La primera contraposición es entre fenoménico y trascendental. El primer término se refiere al mundo exterior, como aparece a nuestras facultades perceptivas. El hombre busca la causa para las diferentes impresiones y sensaciones, y de este modo surge la representación del mundo. Trascendental es aquello que va más allá de estas facultades perceptivas.» 66

El texto muestra que Hellenbach confunde -intencionadamente, o sin pretenderlo- los conceptos de «trascendental» $\mathrm{y}$ «trascendente»: si «trascendental» significaba para Kant las condiciones (imposibles de rebasar) que hacen posible el conocimiento, en Hellenbach este término pasa a significar la posibilidad de obtener un conocimiento supra-fenoménico o metafísico, de tipo espiritual. Esta interpretación de Kant, claramente diferente de la schopenhaueriana, marcará el curso posterior del debate en torno a lo paranormal.

Los fenómenos espiritistas demostrarían, según Hellenbach, la existencia real del mundo de los espíritus, que no sería un simple postulado, como en Kant, sino una realidad trascendental, en la que cada uno de nosotros, gracias a una red de "vibraciones", que trazan un entramado de sutiles «hilos», puede conectar con todas las fuerzas del universo, más allá de su forma de intuición tridimensional: El hombre está unido al mundo entero y todo lo que existe actúa sobre él ${ }^{67}$; y esto le permite, bajo ciertas circunstancias, adquirir unas facultades de percepción y actividad suprasensibles, que pueden ser entrenadas y aumentadas, como demuestran los yoguis y faquires hindúes, y las personas llamadas «sensitivas».

Por otra parte, si ese sujeto trascendental, o espíritu, es independiente de la conciencia, y ésta se encuentra ligada al cuerpo físico, como parece, entonces la conciencia muere con el individuo, mientras que el sujeto

65 Cf. J. C. Fr. ZÖLLNER, Física trascendental, o. cit., pp. 31 y ss.

66 L. B. Hellenbach, Geburt und Tod als Wechsel der Anschauungsform oder die Doppel-Natur des Menschen, Wilhelm Braumüller, Wien, 1885, pp. 12-13.

67 L. B. HellenBACH, Geburt und Tod als Wechsel der Anschauungsform, o. cit., p. $52-53$. 
permanece, porque está dotado de propiedades trascendentales, que le permiten elevarse por encima de las leyes del espacio, el tiempo y la causalidad. Nada impide, entonces, que dicho sujeto haya existido antes del nacimiento y que siga existiendo después la muerte física, en un mundo aparte de espíritus, pudiendo ponerse en contacto con los vivos, como también han admitido las tradiciones ancestrales, para las cuales «la existencia humana solo es un episodio transitorio de la vida propiamente di$c h a »{ }^{68}$. Como «el mundo es nuestra representación», pueden existir otros mundos y seres imperceptibles, de los que no sabemos nada, debido a la limitación de nuestros sentidos, pero que bajo determinadas circunstancias podrían entrar en contacto con nosotros ${ }^{69}$, como sucede en las sesiones espiritistas, aunque siempre de forma parcial e imperfecta, debido a la diferencia que media entre nuestro nivel de existencia y el suyo, así como a la imperfección de nuestros órganos perceptivos, que solo alcanzarán un mayor refinamiento tras la muerte.

El propio Hellenbach es consciente de que su forma de interpretar el ámbito espiritual difiere notablemente de la propuesta por el «Buda de Frankfurt», y se acerca más a la teoría kantiana (tal como él la entiende, por supuesto):

«Nosotros sabemos, efectivamente, que la individualidad va más allá, y aunque Schopenhauer mismo admite esta posibilidad, la discrepancia entre mi filosofía y la de Schopenhauer se acentúa -a pesar de su afinidad- porque Schopenhauer llega a un idealismo trascendental y yo al realismo trascendental. Él llega a la conclusión de que toda la representación del mundo y de la persona es una ilusión, y fuera de la representación, en la realidad, solo hay una "voluntad" inconsciente e impersonal, que hace acto de presencia en el fenómeno; yo digo: toda nuestra representación del mundo y de la persona es una ilusión, en cuyo fondo, empero, existen realidades trascendentales. Por eso en aquellos lugares de las obras de Schpenhauer que tratan del hombre, utilizando la expresión "voluntad", basta con hacer el añadido del "sujeto inteligible", o también sustituir la expresión "voluntad" por esta otra, para constatar, en la mayoría de los casos, una plena coincidencia de ambas perspectivas. Todo lo que yo puse en el hombre a cuenta del sujeto inteligible, lo adjudica Schopenhauer a la voluntad metafísica universal. (...)

He confrontado mi "individualismo" tanto con la filosofía de Schopenhauer y sus ramificaciones (Bahnsen, Hartmann, Mainländer), así como con los sistemas de Leibniz, Herbart, Drossbach y Fichte. Aquí hay que

68 Ibid., p. 258.

69 Ibid., pp. 187-188. 
tener en cuenta mejor la filosofía de Kant, que está en plena concordancia con la mía. Kant dice que el alma y el yo pueden ser el mismo sujeto, pero no la misma persona. (...) Por consiguiente, nuestra personalidad terrestre comienza manifiestamente con nuestro nacimiento y termina con nuestra muerte, no pudiendo ser ambas para el sujeto, en consecuencia, otra cosa que un cambio en la forma de intuición.» 70

No obstante, Hellenbach piensa que ambas concepciones, la suya y la de Schopenhauer, podrían complementarse, pues la voluntad universal puede manifestarse en diversos sujetos espirituales, ejerciendo respecto de ellos un rol parecido al que desempeña el concepto chino del Tao. El problema de Schopenhauer es haber considerado la individuación como una ilusión ${ }^{71}$. En cambio, Hellenbach cree encontrar más afinidad entre su propuesta y la teoría hartmanniana del Inconsciente, puesto que, normalmente, la parte trascendental del ser humano permanece fuera de la conciencia; pero juzga que lo más importante de su aportación es superar el pesimismo de la concepción schopenhaueriano-hartmanniana: si el núcleo central del mundo fuese una voluntad impersonal o el Absoluto inconsciente, y la existencia algo negativo, que hay que negar, como sostienen los adalides de la filosofía pesimista, el hombre tendría que renunciar a cualquier esperanza de mejora; la teoría espiritista permite, en cambio -según Hellenbach- superar el pesimismo sobre nuestra existencia; por eso, de ella «depende el progreso de la humanidad» 72 , ya que asegura un destino de progreso indefinido para el hombre tras la muerte (como, por lo demás, había anticipado Kant de algún modo en su segundo postulado práctico sobre la inmortalidad del alma).

\footnotetext{
70 Ibid., pp. 283-284 y 288. Resulta muy interesante la lista de autores que cita Hellenbach para apoyar su "individualismo", que se remonta, evidentemente, a la monadología leibniciana; destaca, en especial, la referencia a Mainländer y Bahnsen, quienes habían corregido la metafísica schopenhaueriana, ofreciendo una interpretación individualista de la voluntad ( $c f$. Ph. MAINLÄNDER, Die Philosophie der Erlösung, Erster und Zweiter Band, Herausgegeben von W. H. Müller-Seyfarth, Georg Olms Verlag, Hildesheim-Zürich-New York, 1996 [Filosofía de la redención, Ed. y trad. de Manuel Pérez Cornejo y Carlos J. González Serrano, Madrid, Xorki, 2014], y J. BAHnsen, Das Tragische als Weltgesetz und der Humor als ästhetische Gestalt des Metaphysischen, Hrsg. W. H. Müller-Seyfarth, Berlin, Van Bremen, 1995 [Lo Trágico como ley del mundo y el humor como forma estética de lo metafísico, Ed. y trad. de Manuel Pérez Cornejo, Publicacions de la Universitat de València, 2015]).

71 Ibid., p. 284.

72 Ibid., p. 285.
} 


\section{Continuación de la hipótesis inmanente: el escrito anti-espiritista de Eduard von Hartmann}

Ante la propagación del realismo trascendental y la proliferación de las prácticas espiritistas -que lo habían separado de un discípulo tan apreciable como Carl du Prel, y se estaban convirtiendo, según él, en una especie de «plaga», que amenazaba con resucitar formas de superstición medieval-, Eduard von Hartmann se sintió obligado a reaccionar y poner en valor la hipótesis inmanente de Schopenhauer. En 1885 publicó un librito, titulado Der Spiritismus (El espiritismo), donde se apoyaba en el principio básico de su filosofía, lo Absoluto Inconsciente, para tratar de explicar los fenómenos paranormales, sin necesidad de admitir la existencia del mundo de los espíritus ${ }^{73}$.

Von Hartmann propone investigar científicamente estos fenómenos, a fin de averiguar qué fuerzas, siempre naturales, aunque desconocidas hasta ahora, operan en ellos ${ }^{74}$. Para explicar esas fuerzas, existen dos posibilidades: o son efectivamente producidas por la actividad de seres invisibles inteligentes -como juzgan los partidarios del realismo trascendental-, o bien son el producto de una actividad cerebral inconsciente procedente de la voluntad del propio médium que preside estas sesiones, normalmente activada por el magnetizador que actúa a través de él, como sostiene la hipótesis inmanente; ahora bien, en este último caso, también existen dos opciones:

«(...) o la actividad cerebral inconsciente [del médium] en cuestión es absolutamente inconsciente, un proceso puramente material, que sigue caminos mecánicamente prescritos y solo presenta la apariencia de la inteligencia consciente en sus resultados (...), o hay una conciencia sonámbula junto y detrás de la conciencia despierta, que acompaña a estos procesos materiales y mecánicos del cerebro, iluminándolos con una inteligencia real.»75

Von Hartmann piensa que los casos de escritura involuntaria, en los que se redactan textos perfectamente coherentes, dotados de un sentido

\footnotetext{
73 Como señala A. Conan Doyle: «desde el punto de vista de la filosofía de Hartmann, era inadmisible la intervención de los espíritus, y una ilusión la inmortalidad humana.» (o. cit., p. 372)

74 E. von Hartmann, Der Spiritismus, Friedrich V., Leipzig, 1885 (citamos por la ed. inglesa de C. C. Massey: Spiritism, Cambridge University Press, 2012, pp. 14-15).

75 E. von Hartmann, Spiritism, o. cit., pp. 27-28.
} 
inteligible, hablan a favor de la segunda opción, es decir, por «la coexistencia de dos conciencias en diferentes partes del cerebro. Este fenómeno ha de denominarse, por tanto, sonambulismo, pero se trata de un sonambulismo encubierto, que, como está velado, se hace irreconocible para la observación exterior, dada la persistencia de la conciencia despierta.» ${ }^{76}$. El sonambulismo encubierto, o «actividad de la conciencia sonámbula», sería, por tanto, un estado intermedio entre el dominio exclusivo de la conciencia despierta y el sonambulismo normal.

Un médium sería, por tanto, un sujeto que, bien de forma autoinducida, bien con ayuda de un magnetizador externo, cae espontáneamente en un estado de sonambulismo encubierto; y aunque tanto él como aquellos que asisten a la sesión espiritista creen que las manifestaciones paranormales que están presenciando se deben a la acción de inteligencias externas invisibles, en realidad se trata de contenidos ideales producidos por una fuerza nerviosa procedente de la voluntad inconsciente del médium, localizada en las capas medias e inferiores de su cerebro, y situada por debajo de su voluntad consciente ${ }^{77}$. Si a esto se añade la capacidad del médium -caso de que sea él también un potente magnetizadorde condensar la fuerza nerviosa de los asistentes, mediante sugestión, en condiciones de escasa luminosidad, silencio, etc., como las que presiden estas sesiones, pueden perfectamente suscitarse alucinaciones visuales, auditivas o táctiles en las personas que asisten a ellas, de forma que tales alucinaciones llegan a ser tan intensas que terminan por considerarse reales ${ }^{78}$.

Cuando se trata del movimiento de objetos a distancia, no existe una influencia mental inmediata sobre tales objetos, sino «solo de una fuerza física producida bajo la excitación psíquica por el sistema nervioso del médium ${ }^{79}$, es decir, una fuerza natural, no sobrenatural, que, al estar polarizada, puede contrarrestar la fuerza de la gravedad y producir fenómenos tan incré́bles como la levitación, sobre todo si la mencionada fuerza que ejerce la voluntad inconsciente del médium actúa como catalizador de la fuerza nerviosa de los componentes del círculo espiritista ${ }^{80}$. Serían, asimismo, las fuerzas procedentes de la fantasía y la voluntad inconscien-

\footnotetext{
76 Ibid., p. 28.

77 Ibid., pp. 24 y ss.

78 Ibid., pp. 52-53.

79 Ibid., p. 35.

80 Ibid., pp. 37-38.
} 
tes del médium las que permitirían explicar la condensación de partes de su materia corporal en las llamadas «materializaciones»:

«(...) los fantasmas de las, así llamadas, sesiones de materialización son -después de todo lo que puede decirse de ellas hasta el presente- realmente solo fantasmas, $i$. e. fenómenos subjetivos sin realidad objetiva, fenómenos cuyo asentimiento relativo por parte de los espectadores se explica por su origen en la alucinación sonámbula del médium, transferida a éstos.» 81

Asimismo, la escritura con letra ajena, así como la capacidad para penetrar en el interior del cerebro de otras personas, o de transmitir a distancia los pensamientos (telepatía), con «un poder tan grande que, si se trata, además, de personas con un rapport simpático, basado en el amor, la amistad o en relaciones magnéticas, puede superar toda distancia terrena», se deben a que «la conciencia sonámbula no está inmediatamente sujeta a la voluntad consciente» 82 : aquí todo depende de la sensibilidad, tanto del agente como del recipiendario, y de lo estrecha que sea la relación entre ambos. De hecho, Von Hartmann cree que

«(...) si dos personas han practicado primero esta comunicación a distancia, la conexión entre ellas puede restablecerse en cualquier momento, por la voluntad de una de ellas de dirigirse a la otra, excitando en esta última al principio un sentimiento indefinido, o la aparición de una luz distante, o alguna indicación que sirve de señal, y que le hace a él mismo entrar en un estado de sonambulismo, para la percepción de representaciones (Vorstellungen) definidas. De este modo, los iniciados de los altos grados de las hermandades secretas del Tíbet han adquirido el poder de conversar entre sí a distancia, sin hilos telegráficos, y logros similares han tenido lugar en Europa.»83

La distinción entre la clarividencia y la lectura del pensamiento radica en que en ésta última únicamente son percibidos pensamientos de personas presentes, debido a cierta resonancia de la conciencia sonámbula del propio sujeto perceptor, mientras que en la clarividencia se trataría de la visión de objetos reales lejanos, sin la mediación inmediata de los sentidos $^{84}$. Cuando la clarividencia es muy intensa, parece claro que hay que

\footnotetext{
81 Ibid., p. 101.

82 Ibid., pp. 59 ss.

83 Ibid., p. 60.

84 Ibid., p. 71.
} 
reconocer una facultad de sobrepasar espiritualmente el espacio y el tiempo. Por eso, la alucinación que anuncia el futuro a la conciencia es evidentemente sólo el último resultado de un proceso psíquico absolutamente inconsciente, que, como tal, no necesita mediación sensible, ni material, y que Hartmann considera que sólo puede aclararse recurriendo a una explicación metafísica suprasensible, a una especie de «correspondencia telefónica en el Absoluto»:

«Al enfrentarse a estos hechos, o uno concede al alma individual la facultad del conocimiento absoluto -es decir, de un conocimiento no limitado por el tiempo-, o uno va más allá del alma individual hasta su raíz esencial en el espíritu absoluto; en ambos casos no se necesita de ninguna asistencia, ni externa, ni intermedia, y menos aún la de los espíritus de los difuntos, que son aún almas individuales.

En el primer caso, las mónadas o individuos están escindidas de su fundamento absoluto, del cual han debido brotar necesariamente, y se les adscribe una propiedad que solamente les atañe en relación al Absoluto; el segundo caso, sugiere la indestructible conexión de cada criatura con su naturaleza, que es la madre universal, y la reflexión de que, por consiguiente, en este ombligo espiritual debe circular una savia de la que la conciencia no tiene normalmente aprehensión alguna. Si todos los individuos de orden superior o inferior están enraizados en lo Absoluto, retrogradando en éste, ellos tienen una segunda conexión entre sí, y solamente se requiere la restauración del rapport o de la conexión telefónica (Telephonanschluss) entre dos individuos en lo Absoluto, por un intenso interés de la voluntad, para que se produzca el intercambio espiritual inconsciente entre ellos, sin mediación de los sentidos (...). El fuerte interés de la voluntad sirve para motivar tales funciones inconscientes, que actúan inspirando la conciencia sonámbula.

En la conciencia absoluta del espíritu absoluto todos los hilos de las series causales están idealmente enlazados en una única intuición colectiva, de manera que, desde ésta, es predeterminable incluso lo que aparece como accidental en los eventos del futuro. La omnisciencia del espíritu absoluto abarca implícitamente tanto el futuro como el pasado; por eso el individuo, mediante un intenso interés de la voluntad, puede esbozar inconscientemente desde el conocimiento inconsciente del espíritu absoluto, tanto los detalles de los eventos futuros, como los particulares del estado presente del mundo en puntos distantes. (...) Desde este punto de vista monístico-concreto, resulta inteligible que el fuerte interés de la voluntad del alma individual baste para liberar, sin perjuicio de la distancia, funciones en el sujeto absoluto que están dirigidas sobre el organismo de otro individuo, hasta el punto de que parece estar integrando constituyentes o funciones del alma individual pertenecientes a este organismo. Con la acción excitante o inspi- 
radora sobre las partes sonámbulas del cerebro de las funciones así liberadas, está preparada la transferencia de alucinaciones a la conciencia sonámbula de los demás.» 85

Von Hartmann advierte que este recurso a una experiencia suprasensible, no introduce hipótesis trascendentes, como hace el espiritismo, sino que se basa simplemente en el natural enraizamiento de los individuos en lo Absoluto Inconsciente, un principio que no puede ser objetado por el materialismo. Es verdad que esta explicación trasciende la esfera de lo meramente natural, pero solo para retrotraerse a la raíz supra-natural de lo dado naturalmente, sin la cual éste último no tendría ni esencia, ni existencia; pero no es sobrenatural, en el sentido de que apele a una esfera oculta de individuos escondida detrás de lo dado. Tan solo rechaza abstraer lo natural de su base supra-natural, considerándola más bien en su concreta unidad con esta última, que le es inmanente como ser y sustancia.

Irónicamente, Von Hartmann señala que el descubrimiento contemporáneo de la telegrafía hace innecesaria la comunicación telepática practicada por los monjes tibetanos (muy confusa e inexacta); por otra parte, argumentando como pesimista, considera que no es deseable fomentar la clarividencia, porque lo que hace soportable la vida es precisamente nuestro desconocimiento del futuro, que nos deja al menos un espacio para la esperanza y el esfuerzo; esto sin contar con que tener la capacidad de anticipar la muerte de personas conocidas, o los sufrimientos y desastres futuros, podría llegar a ser más bien una suerte de maldición, en una vida ya de por sí llena de cosas tristes ${ }^{86}$.

La conclusión a la que llega Von Hartmann en el Capítulo V de su libro, es que la hipótesis espiritista, aunque comprensible, por el deseo que todos tenemos de proseguir el trato con las personas queridas que han fallecido, es propia de sujetos con poca capacidad crítica, que quedan fascinados por la influencia de los médiums y las alucinaciones que éstos les inducen. Acabamos de ver que, excepto la verdadera clarividencia, la explicación del resto de los fenómenos paranormales no necesita salirse de los cauces naturales ${ }^{87}$ : la mayoría de los fenómenos tendrían su origen en la fuerza nerviosa del médium, que impulsa su voluntad inconsciente.

85 Ibid., pp. 75-76.

86 Ibid., p. 80. La sensibilidad paranormal como carga incómoda para quien la posee, ha sido abordada por Clint Eastwood en Más allá de la vida (Hereafter, 2010), película en la que el principal protagonista, el médium George Lonegan (Matt Damon), vive su don para visionar el Más Allá como una terrible condena personal.

87 Ibid., p. 101. 
Esto parece lógico, porque los fantasmas, tanto si están libres del cuerpo, como si tienen un «cuerpo astral»o «etéreo» (un «meta-organismo»), han de pertenecer a un orden de cosas completamente distinto al nuestro, de manera que no van a rondarnos con una forma de las mismas dimensiones espaciales que el organismo que dejaron atrás al morir, y en caso de que quisieran manifestarse, no necesitarían la intervención de ningún médium. Como el espiritismo reconoce esto, considera que tanto los fenómenos físicos como los fenómenos de materialización son producidos por el médium, pero bajo la dirección de los espíritus, que controlarían su voluntad e inteligencia «desde detrás», sin intervenir ellos mismos directamente en el mundo. Serían meros autores intelectuales de los fenómenos, asumiendo su faceta psíquica, mientras que el médium se encargaría de la parte corporal. Esta hipótesis de la posesión falla, sin embargo, porque parte de una psicología que solo atiende a los contenidos de la conciencia normal despierta, sin sospechar que existen deseos, sentimientos e ideas relativamente, o absolutamente inconscientes, que aparecen en el estado de sonambulismo, y que, por lo demás, coinciden con los contenidos propios del nivel intelectual y las ideas del propio médium: por tanto no es un supuesto «espíritu» foráneo el que controla la mente del médium, sino que los deseos, sentimientos e ideas que se requieren para la manifestación espiritista proceden de la conciencia sonámbula de éste último, ligada a las partes inferiores y medias del cerebro, a las que nos hemos referido antes ${ }^{88}$.

La hipótesis de la posesión cede paso, entonces, a la hipótesis de la inspiración, según la cual es la conciencia sonámbula del médium la que actúa en las sesiones espiritistas, pero «inspirada» por los contenidos que la conciencia del espíritu controlador introduce en ella. Hemos visto que cabe la posibilidad de una transmisión de pensamientos entre los hombres, de manera que puede admitirse que un espíritu inspire también ciertos pensamientos en el hombre; mas, ¿cómo podría hacerlo?, pues el espíritu del difunto no tiene cerebro (objetivación de la voluntad), cuyas vibraciones podrían inducir cambios en la fuerza nerviosa de otro cerebro. Hartmann concluye, por tanto, que

«(...) toda la hipótesis espiritista se resuelve ella misma en una pura nada, cuando primero las acciones directas de la fuerza física, luego las producciones de los fenómenos de materialización y, finalmente, la idealidad de las manifestaciones, han sido trasladadas desde los supuestos espíritus al

88 Ibid., pp. 106-109. 
médium. No vamos a investigar aquí si hay espíritus o no; se trataría de entes que, si existen, quedan relegados a ese Más Allá que el espiritismo piensa haber descrito aquí abajo.» 89

Resumiendo: el espiritismo, aunque pretende ser «científico», carece de rigor, desde el momento que admite causas sobrenaturales detrás de los fenómenos paranormales, cuando, para explicarlos basta el poder natural que emana del médium sonámbulo inconsciente:

«Hay una serie de axiomas metodológicos generales que no pueden transgredirse impunemente. En primer lugar, los principios no han de multiplicarse sin necesidad, de manera que no hay que suponer una segunda serie de causas cuando basta una sola. En segundo lugar, debemos admitir, en lo posible, aquellas causas cuya existencia esté garantizada por la experiencia o una influencia indudable, y no acudir innecesariamente a causas de existencia dudosa o no probada, como han de serlo aquellas que poseen valor de hipótesis para la explicación de los fenómenos en cuestión. En tercer lugar, debemos intentar, hasta donde sea posible, manejar causas naturales, y no tocar las sobrenaturales, sin una necesidad realmente urgente. El espiritismo atenta contra estos tres axiomas. Reconoce, desde luego, el tipo de causa natural, dada empíricamente, que poseemos en el médium, pero junto a ella pone una segunda causa de tipo sobrenatural, no dada empíricamente, cuya existencia ha de ser probada, al menos una vez, para este sector de fenómenos. (...) El espiritismo debe empeñar todas sus fuerzas en definir exactamente la línea fronteriza más allá de la cual cesa el poder explicativo del primer tipo de causas, y mostrar con una crítica cuidadosa por qué cesan de ser suficientes más allá de esta línea (...), recayendo la carga de la prueba en quien afirma la segunda clase de causas; mas el espiritismo no ha hecho el más mínimo intento de ajustarse a esta obligación. Mientras esto no se haga, la hipótesis espiritista adolece de falta de fundamentación y de garantía científica, y todos los filósofos que han adoptado el espiritismo han mostrado por eso una seria deficiencia de circunspección crítica.» 90

\section{Prosecución y desarrollo del realismo trascendental: Aksakov y Du Prel}

En una época en la que aún dominaba el espíritu caballeresco, dos espiritistas recogieron el desafío lanzado por Hartmann al final de su escrito, y se esforzaron en definir exactamente esa línea fronteriza que debe

89 Ibid., p. 112.

90 Ibid., pp. 112-113. 
marcar el límite explicativo de las causas naturales: el ruso Alexander Aksakov, con su libro Animismus und Spiritismus (Animismo y espiritismo, 1890), y su antiguo seguidor, Carl du Prel, que publicaría en 1893 Der Spiritismus (El espiritismo), un escrito en el que proponía una explicación de los fenómenos paranormales en el marco del evolucionismo darwinista.

En su extensísima obra, que contiene una exhaustiva fenomenología paranormal, Aksakov cree demostrar que la hipótesis espiritista no puede excluirse en absoluto a la hora de explicar determinados fenómenos ocultos, que, por su índole intelectual, obligan a recurrir a una causa inteligente ajena al médium ${ }^{91}$. Por eso introduce el término «animismo», para referirse a todos aquellos fenómenos -incluso efectos físicos y plásticos extracorporales- que pueden atribuirse a la actividad inconsciente del hombre $^{92}$. Aplicando este criterio, Aksakov señala que existen tres hipótesis para explicar los fenómenos paranormales ${ }^{93}$ :

$\left.1^{a}\right)$ La hipótesis personalista, que explica los fenómenos (mesas giratorias, escritura, habla inconsciente...) dentro de los límites de la esfera corporal del médium, pareciendo que su personalidad está poseída por la de otra persona, porque se produce un desdoblamiento de la conciencia; estos fenómenos, que coinciden con los explicados por el sonambulismo inconsciente de Hartmann, demostrarían la dualidad del ser psíquico, existiendo un "yo individual interior inconsciente", que puede proyectarse de forma independiente, y que no se identifica con el "yo personal exterior consciente".

$\left.2^{\mathrm{a}}\right)$ La hipótesis animista, que explicaría los fenómenos psíquicos inconscientes extra-mediúmnicos, es decir, producidos fuera de los límites de la esfera corporal del médium (transmisión inmediata del pensamiento o telepatía, movimiento de objetos sin contacto, materializaciones) y que supone la cúspide del desdoblamiento psíquico, de manera que los elementos de la personalidad franquean los límites del cuerpo y se manifiestan a distancia, mediante efectos no solo psíquicos, sino también físi-

91 A. AKsakov, Animismus und Spiritismus, Mutze, Leipzig, 1890, 2 Bände (2ª Ed. 1894); utilizo la edición francesa: Animisme et spiritisme. Essai d'un examen critique des phénomenes mediumniques, spécialement en rapport avec les hypothéses de la "force nerveuse", de l'"hallucination" et de l'"inconscient", comme réponse à l'ouvrage du Dr. Ed. von Hartmann intitulé "Le spiritisme" (1885). Traduit de l'édition russe par Berthold Sandow. Troisième édition. Paris, Librairie des Sciences psychiques, Paul Leymaire, 1906, p. XIX.

92 Ibid., pp. XXII-XXIII.

93 Ibid., pp. XXIII-XXV. 
cos; para Aksakov, este tipo de fenómenos demostrarían la existencia de lo que los filósofos-espiritistas, como Hellenbach, llaman «alma», o «metaorganismo».

$\left.3^{a}\right)$ Finalmente, la hipótesis espiritista, que haría referencia a aquellos fenómenos, aparentemente personalistas y animistas, pero que reconocen una causa extra-mediúmnica y supra-terrestre, es decir, fuera de la esfera de nuestra existencia.

El problema es que estos últimos fenómenos son muy semejantes a los anteriores; solo se distinguen de ellos por su contenido intelectual, y como a menudo las tres hipótesis pueden servir para explicar un mismo hecho, los espiritistas más fanáticos han querido atribuir todos ellos a la acción de los espíritus, mientras que los partidarios de la hipótesis inmanente, como Von Hartmann, han pretendido reducirlos al sonambulismo encubierto, a la acción de la voluntad o a una conexión a través del Absoluto Inconsciente; pero Aksakov sostiene que ambos partidos se equivocan: hay fenomenología que no requiere acudir a la hipótesis de los espíritus, y hay determinados fenómenos que ineludiblemente exigen como causa una personalidad extra-corporal independiente ${ }^{94}$.

Las materializaciones de formas y figuras, invisibles a simple vista, captadas mediante la fotografía trascendental; las comunicaciones complejas, transmitidas por personas de muy baja formación intelectual, y otros fenómenos que muestran una intencionalidad intelectual muy definida, no pueden reducirse a meras alucinaciones provocadas por el médium sonámbulo, como cree Von Hartmann, pues aquellos que asisten a las sesiones espiritistas no están dormidos, ni hipnotizados, sino más bien lo contrario; de manera que la tesis hartmanniana, según la cual el médium y los asistentes comparten una especie de «ensueño colectivo», pero sin dormir, es, cuando menos, aventurada ${ }^{95}$. Von Hartmann comete, asimismo, el error de atribuir los fenómenos de clarividencia y telepatía a esa conexión metafísica que, según él, une a los individuos en el plano del Absoluto Inconsciente, porque, de ser así -indica Aksakov- como ese Absoluto supuestamente «lo sabe todo», las visiones deberían ser completamente nítidas y claras, mientras que lo que

\footnotetext{
94 «El animismo abarca aquellos fenómenos cuya causa es el médium, mientras que el espiritismo se refiere a aquellos otros cuya condición es el médium, pero cuya causa radica en un ser inteligente invisible, visible sólo excepcionalmente.» (C. du PREL, Der Spiritismus, Sarastro Verlag, Paderborn, 2012, p. 35)

95 Ibid., p. 253.
} 
sucede es justo lo contrario: por lo general, las visiones suelen ser parciales e imperfectas ${ }^{96}$.

La teoría de Von Hartmann encuentra, pues, en el dominio de los hechos intelectuales, a juicio de Aksakov, «un Rubicón que no puede franquear» con su teoría del sonambulismo ${ }^{97}$. Abundante fenomenología demuestra la acción de una voluntad orientada racionalmente, diferente de la del médium ${ }^{98}$ (algo que, por lo demás, coincidiría, según Aksakov, con la metafísica hartmanniana, que reconoce la voluntad como la causa que subyace a esa representación ilusoria que llamamos ««materia» ${ }^{99}$ ); esa voluntad revelaría la existencia de un «ser trascendental individual»100, situado fuera del médium y «de las condiciones del tiempo y del espacio que nos resultan conocidas». Ese ser trascendental, «o es alguien vivo, o alguien que vivió, pero ya no vive, o bien un ser extraterrestre de especie desconocida para nosotros»101. Aksakov deja de lado la hipótesis extraterrestre, considerándola solo una «posibilidad lógica»102 y retoma la tesis de Hellenbach de que el hombre posee una naturaleza dual, con dos conciencias: una exterior (la normal, o personalidad) y otra interior: el yo o sujeto trascendental (que es su identidad), aparentemente independiente del primero, y que está dotado de una inteligencia y voluntad propias, junto con una facultad de percepción extraordinaria, no limitada por el tiempo ni el espacio, todo lo cual le permite actuar por sí mismo, al margen de la conciencia normal ${ }^{103}$. Mientras ésta última está ligada al cuerpo, la conciencia interior (el «alma») tiene una conexión fortuita con ella, de manera que cabe admitir perfectamente la posibilidad de que dicha conciencia conserve su existencia independiente, incluso en ausencia del cuerpo:

96 Ibid., pp. 396 y 469.

97 A. AKsAKOV, Animisme et espiritisme, o. cit., pp. 371-372.

98 Ibid., pp. 260-342. Aksakov menciona casos extraordinarios, como los de esos niños pequeños, que apenas saben escribir y redactan documentos muy sofisticados; médiums que hablan lenguas que les son desconocidas; la finalización de la novela inacabada de Ch. Dickens The mystery of Edward Drood (1873) por el inculto médium James, bajo la supuesta dirección del espíritu del escritor fallecido, o la explicación del movimiento retrógrado de los satélites de Urano por un astrónomo fallecido en 1858, relatado por A. W. Drayson en The solution of scientific problems by spirits (Light, 1884).

99 Cf. E. von Hartmann, Die Philosophie des Unbewussten, Fünfte, neu durchgesehene und vermehrte Auflage, Berlin, Carl Dunckers Verlag, 1873, p. 479.

100 A. AKsakov, Animisme et espiritisme, o. cit., p. 397.

101 Ibid., p. 468.

102 Ibid., p. 470

103 Ibid., pp. 470-524. 
«Si queremos admitir la hipótesis espiritista, parece claro que no es sino este núcleo interior, este principio individual, lo que puede sobrevivir al cuerpo y todo aquello que pertenece a su personalidad terrestre no será para él más que una cuestión de memoria.

He aquí la clave para la inteligencia de los fenómenos espiritistas. Si el sujeto trascendental ha estado unido al cuerpo durante su manifestación fenoménica, no es ilógico admitir que, después de la descomposición del cuerpo, esta manifestación pueda revelarse de una forma o de otra en el mundo fenoménico por mediación de algún otro organismo humano, más o menos accesible a las impresiones de orden trascendental. (...) En otras palabras: la individualidad permanece, la personalidad desaparece. (...) [No obstante] ese mundo trascendental es una noción tan inconmensurable para el mundo fenoménico como la cuarta dimensión; no podemos -hay que convencerse de esta verdad- hacernos ninguna idea de él.»104

Basándose en el contenido intelectual de los fenómenos mediúmnicos, y en esta aparente independencia del ser interior del sujeto respecto del cuerpo, Aksakov plantea un razonamiento analógico:

«Si recibimos por vía mediúmnica una comunicación que porta todas los indicios que caracterizan a una persona viva, como nosotros, y si encontramos lógico y natural relacionar esta comunicación con esta persona viva, que es la causa eficiente de esta manifestación, ¿no sería también absolutamente lógico, en el caso de una comunicación que posee todos los rasgos característicos de una persona que hemos conocido entre los vivos, pero que ya no existe, relacionar esta comunicación igualmente con esta persona, y concluir que ella es, de una forma u otra, la causa eficiente de esta manifestación?»105

Razonamiento que extiende a la aparición de un fantasma: si a B se le aparece un individuo A (vivo), no piensa que es una creación de su mente, sino que considera que su visión está provocada por la presencia real de A; análogamente, si nos encontramos con una serie de manifestaciones (estilo de escritura, uso de una lengua desconocida para el médium, detalles de la vida íntima desconocidos para los presentes, etc.), que solo cabe atribuir a un individuo ya fallecido, no queda más remedio que atribuirles como

104 Ibid., pp. 536-537.

105 Ibid., pp. 533-534. Podría objetarse que los espiritistas como Aksakov caen en un razonamiento circular, porque parten de los fenómenos paranormales para inferir la existencia de un sujeto trascendental, y luego consideran que es ese mismo sujeto el que produce tales fenómenos; pero, igual que Kant, podría introducirse aquí la distinción entre ratio cognoscendi y ratio essendi, que desharía la falacia circular: los fenómenos paranormales serían la ratio que nos permite conocer la existencia del sujeto trascendental y éste, por su parte, sería la causa de tales fenómenos. 
causa el «espíritu» (es decir, la inteligencia y la voluntad) del difunto106, sin que quepa considerar que esos datos constituyen una alucinación:

«Admitimos como algo lógico que un "espíritu" ha de hallarse fuera del tiempo y del espacio, y al mismo tiempo le prestamos un cuerpo y una forma, es decir, los atributos que dependen necesariamente del espacio y del tiempo. Se trata de una contradicción evidente. La filosofía crítica, muy justamente, se guarda de caer en esta contradicción, burlándose de la doctrina de los "espíritus" y de sus manifestaciones. Niega la existencia individual tras la muerte, basándose, precisamente, en el axioma kantiano de que espacio y tiempo no son más que formas de nuestra intuición, que dependen de nuestro organismo terrestre; una vez desaparecido este organismo, tales formas de intuición ya no existirían y, por consiguiente, también desaparecería la personalidad, que depende de las ideas del tiempo y del espacio. Pero si la cosa en sí existe, como admite esta misma filosofía, no en la unidad, sino en la multiplicidad, podemos suponer que también el espíritu humano, el principio individual, es una de las cosas en sí, y por consiguiente sus relaciones con las otras cosas en sí determinarían también las formas de intuición y de concepción que le son propias y que no tendrían nada en común con las nuestras. Una mónada es un centro de fuerza y de conciencia, con un grado superior de desarrollo, o dicho de otro modo, una entidad individual dotada de inteligencia y de voluntad: he aquí la única definición que podríamos atrevernos a dar del concepto de espíritu. En el momento en que ella se manifiesta de nuevo en el plano terrestre, debe revestir necesariamente la forma humana terrestre. También una aparición sensible y tangible no sería más que una objetivación temporal de una mónada humana, revistiendo un carácter de personalidad en el mundo fenoménico.»107

Con lo cual Aksakov vuelve a Kant, pero sustituyendo los data éticoprácticos, en los que él se basaba para postular la existencia del mundo de los espíritus, por los datos «experimentales» ofrecidos a posteriori por las sesiones espiritistas:

«El gran mérito del espiritismo es, precisamente, haber probado que las cuestiones más misteriosas que se relacionan con el problema de nuestra existencia pueden ser estudiadas por la vía experimental.»108

En 1891, Von Hartmann replicaría a Aksakov en Die Geisterhypothese des Spiritismus und seine Phantome (La hipótesis de los espíritus del espiritismo y sus fantasmas), reafirmándose en su inmanentismo impeni-

\footnotetext{
106 Ibid., p. 624.

107 Ibid., p. 628

108 Ibid., p. 634
} 
tente, asumiendo esta vez Carl du Prel -quien había conocido a Aksakov en 1886, y empezado a colaborar con él- la tarea de responderle con su escrito Der Spiritismus (1893). El capítulo II de este libro está dedicado a rebatir la teoría hartmanniana del sonambulismo inconsciente y la alucinación, con los argumentos que ya conocemos ${ }^{109}$, y el resto a apoyar el realismo trascendental de Hellenbach y Aksakov mediante la teoría darwiniana de la evolución. En su libro Die Planetenbewohner (Los habitantes de los planetas, 1880) Du Prel había señalado, siguiendo a Kant, que el problema de la teoría del conocimiento depende de nuestras capacidades sensoriales e intelectuales, de manera que una alteración, por mínima que fuese, de estos factores alteraría nuestra manera de conocer la realidad. Nuestro organismo está adaptado solamente a ciertas vibraciones del éter, pero pueden concebirse multitud de seres diferentes, que existirían más allá de estas condiciones; además, esos seres, al tener otras formas de percibir la realidad, adecuadas a otras vibraciones, habitarían también mundos diferentes, inimaginables para nosotros.

Partiendo de estos presupuestos, Du Prel propone un darwinismo trascendental110: la cadena evolutiva se extiende más allá del hombre, e incluso por encima del nivel físico de la naturaleza, hacia otros mundos, habitados por seres inmateriales o espirituales.

Cabe pensar, por tanto, en estados como el sonambulismo, que pondrían al hombre en contacto momentáneo con algunos de esos otros mundos; tales estados demuestran, como habían sostenido Hellenbach y Aksakov, que más allá de la conciencia se oculta un núcleo de ser más profundo ${ }^{111}$, no ligado al cuerpo, como ella, que seguramente pervive tras la muerte. A ese sujeto trascendental es al que habría que atribuir las capacidades ocultas que aparecen en los fenómenos paranormales, ya que él posee su propio modo de representación y de acción, independiente del cuerpo físico y de la conciencia que le está asociada112. Todo esto es tan científicamente posible como que un animal puede haber evolucionado hasta convertirse en un «habitante de dos mundos», o, como lo define Du Prel, «un anfibio de orden superior» 113 .

109 C. du PREL, Der Spiritismus, o. cit., pp. 25 y ss.

110 Ibid., p. 8.

111 Ibid., p. 10.

112 Ibid., p. 14.

113 Ibid., p. 13. La expresión la ideó Johann Christian Cuno para definir a Swedenborg: "especie de anfibio, habitante de dos mundos [físico y espiritual]." (Cf. E. SwEDENBORG, El habitante de dos mundos, o. cit., p. 13). 
Así pues, es la propia ley científica de la evolución (Entwicklung) la que lleva a plantear la continuidad de la cadena evolutiva "por arriba», y barajar la posibilidad de seres evolutivamente superiores, dotados de capacidades de conocimiento mucho más amplias y sutiles. La existencia del mundo de los espíritus no sería, por tanto, un simple "postulado", como había pensado Kant en la época pre-darwinista, sino una posibilidad científica, avalada nada menos que por la teoría de la evolución, en conjunción con los planteamientos del idealismo trascendental (¿qué puede haber más científico?); por eso Du Prel afirma, rotundo, que «el ocultismo es solamente ciencia natural desconocida (unbekannte Naturwissenschaft) [y] será demostrado por la ciencia natural del futuro. (...) El espiritismo es, por consiguiente, el reverso lógico del darwinismo y del problema de la teoría del conocimiento» ${ }^{114}$. La objeción que le plantean los materialistas toscos, acusándole de rebasar las leyes de la naturaleza, se desvanece, porque los fenómenos que rigen los fenómenos espiritistas «no están en contradicción con la ciencia, sino con nuestro saber [actual]»115:

«Aquellos eruditos que, nada más oír la expresión "Más Allá" elevan sus ojos inmediatamente al cénit, allí donde, invocando a Copérnico, nada ven, tendrían incluso más difícil que los legos llegar a entender que solo podemos descubrir el Más Allá sumergiéndonos en nuestro propio interior. (...) Debemos, ante todo, tener en cuenta siempre que no podemos hablar de Más Acá y de Más Allá en un sentido espacial, sino en un sentido subjetivo, gnoseológico. Kant ha dicho que el Más Allá no es otro lugar, sino solamente otro estado; Hellenbach dice que el nacimiento y la muerte son solamente un cambio en las formas de intuición, y estos dos enunciados pueden resumirse brevemente en esta proposición: el Más Allá es el Más Acá, intuido de manera diferente. Las relaciones en la naturaleza de las que es consciente un ser configuran su Más Acá; las de otros seres que él desconoce, así como aquellas que le son propias y de las que no es consciente, constituyen su Más Allá. Por consiguiente, puede haber innumerables Más Acá y Más Allá, pues en la naturaleza están dadas incontables relaciones, y también innumerables series de seres, y también innumerables umbrales de sensibilidad, que separan a cada serie de seres del gran todo de la naturaleza.»116

Du Prel concluye, pues, que la posición que un hombre adopta ante el espiritismo depende tanto de la experiencia de los fenómenos ocultos

114 Ibid., p. 15-16.

115 Ibid., p. 20.

116 Ibid., pp. 20-21. Curiosamente, esta hipótesis ha sido retomada por algunos excéntricos ufólogos actuales, como D. Icke y D. Parcerisa, entre otros. 
-que, como nudos hechos, se imponen «brutalmente»-, como de su «capacidad de reflexión filosófica» ${ }^{117}$, pues exige de él una fuerte preparación en el ámbito de la teoría del conocimiento, que pocas personas poseen:

«Se debe poder dudar del Más Acá para poder creer en el Más Allá. Por eso es completamente comprensible que filósofos que han planteado su sistema sobre el problema gnoseológico -Kant y Schopenhauer-y que, por tanto, dudaban del Más Acá, finalmente hayan llegado a la mística, mientras que los materialistas, que no dudan en absoluto del Más Acá (...), sienten un verdadera estremecimiento en cuanto se les habla del Más Allá y de los espíritus. (...).

Se puede también llegar a ser [espiritista] por el camino del pensamiento, prescindiendo por completo de la experiencia; y, por cierto, se debe, incluso, llegar a serlo, si este pensar es suficientemente consecuente. (...) Pues la más alta certeza que puede alcanzar el hombre está dada cuando casan la lógica y los hechos de la experiencia.»118

Cabe pensar, en definitiva, que la multiplicidad de seres que pueden existir en la naturaleza va mucho más allá de lo que la ciencia y la fantasía humanas pueden imaginar. La «oscuridad metafísica» que padecemos se debe a nuestras limitaciones gnoseológicas, que nos impiden aprehender otros mundos, tanto físicos como espirituales, de los que, no obstante, el sonambulismo y el espiritismo nos ofrecen un pequeño atisbo. Pero lo que hay que tener muy claro -afirma Du Prel- es que «el mundo no es un mosaico», sino que esos mundos, que ahora nos parecen separados, pueden no estarlo para generaciones futuras, espiritualmente más evolucionadas ${ }^{119}$. Entretanto, a la espera del advenimiento de una ciencia más comprensiva, capaz de abrirse a nuevos campos teóricos y experimentales, la conclusión a la que cabe llegar le parece a Du Prel muy evidente, y favorable al optimismo: «Los fenómenos espiritistas son hechos (...) [que] prueban la existencia y la permanencia de un alma individual, y esta intui-

117 Ibid.

118 Ibid., pp. 21 y 24. La cuestión es: ¿cabe calificar las posiciones de Kant y Schopenhauer de «místicas»? Si este término significa para Du Prel «trascendentales o idealistas», no veo dificultad en su utilización, pero parece muy dudoso atribuírselo a ambos filósofos en el sentido habitual del término, que va ligado más bien al ámbito de lo «trascendente», tan solo postulado por Kant, y explícitamente rechazado por Schopenhauer. En cualquier caso, en 1888 Du Prel publicó una edición comentada de las Vorlesungen über Psychologie de Kant, en la que vuelve a atribuirle la creación de un sistema de «mística» (?), al que únicamente le habría faltado la confirmación experimental, proporcionada en su tiempo por el espiritismo.

119 Ibid., p. 23. 
ción debe influir necesariamente de un modo favorable en nuestra concepción global del mundo y de la vida, y también en nuestra orientación vital.»120 El mérito del espiritismo, como había señalado Aksakov, es «haber intentado garantizar la naturaleza trascendental de hombre, y que éste está llamado a un destino superior al de la existencia fenoménica.»121 Los trabajos ulteriores de Carl Gustav Jung122, y en nuestro país de Germán de Argumosa, así como la sorprendente convergencia que estamos presenciando en estas primeras décadas del siglo XXI entre el mundo de lo paranormal y la física cuántica ${ }^{123}$ (anticipada también en sus últimos años por el mismo Jung124), prueban que el debate entre inmanentismo y realismo trascendental, lejos de haber concluido, ha madurado y se ha enriquecido extraordinariamente. Todo apunta a que en este terreno nos aguardan sorpresas, que actualmente resultan difíciles de predecir.

120 Ibid., p. 70.

121 Citado por Du Prel, ibid., p. 71.

122 C. G. JUNG, "Acerca de la psicología y patología de los llamados fenómenos ocultos" (1902), en: Obra completa. Volumen I. Estudios psiquiátricos, Madrid, Trotta / Fundación C. G. Jung, 1999, pp. 1-92.

123 Cf., por ejemplo, los asombrosos estudios del Dr. Pim van Lommel, expuestos en Consciencia más allá de la vida, Atalanta, Girona, 2012; o los testimonios recogidos por Peter y Elizabeth Fenwick en El arte de morir, Atalanta, Girona, 2015.

124 CARL Gustav Jung, "Synchronizität als ein Prinzip akausaler Zusammenhänge", en: Naturerklärung und Psyche, Zürich, Rascher Verlag, 1952, pp. 1-90 (Trad. esp.: "Sincronicidad como principio de conexiones acausales", en: C. G. JunG, Obra completa. Volumen 8. La dinámica de lo inconsciente, Madrid, Trotta / Fundación C. G. Jung, 2004, pp. 415-506. 